\title{
LOCAL ELECTIONS, LOCAL ACTORS AND POLITICAL PATRONAGE NETWORKS (Understanding Involvement of Coal Mining Bosses in the Local Elections in South Kalimantan Province
}

\author{
Murdiansyah Herman \\ murdiansyahuniska@gmail.com \\ Muhammad Uhaib As'ad \\ uhaibm@yahoo.com \\ Faculty of Social and Political Sciences at Islamic University of Kalimantan, \\ Banjarmasin \\ Indonesia
}

\begin{abstract}
This article analyses the political drama of the fall Soeharto's government in May 1998, after 32 years in power, has made a new era of this country democratic life. The fall of the Soeharto's government which gave to a new era of democratization has changed of political landscape from the authoritarian system to the transition of democracy. The democratic transition has had an impact on the almost uncontrollable political dynamics. It also provides an opportunity for central and local political actors to consolidate power and reposition themselves to capture of power institutions and democratic institutions through contestation of local elections. In the capitalization democracy, political pragmatism structured in democratic behavior has spawned the costly cost of democracy. Therefore, it has become a fact in the current reality of democracy that political actors who occupy the stage of democracy are people who have capital (money) or background as entrepreneurs. The involvement of mine bosses in the local elections in South Kalimantan as sponsors of political fund or as candidats local rulers has spawned a black market of democracy characterized by political concessions and transactions through a network of political patronage. South Kalimantan is known as a coal mining product, mining issues in the local election became political marketing to build political patronage networks among local actors. In the context of open competition in local elections, the issue of political funding becomes the most crucial in the democratic transition. The political brokers will position themselves as shadow government after local election in government and become as a controler in policy government, especially mining policy. The mine bosses have of bergaining position in the political landscape and political patronage network to place the people who occupy the position of the local head by power money and oligarchy of political party. The heads of political parties or political elites in South Kalimantan are majority as mine bosses. Thus, the existence of political parties has been taken drive by capitalist. The cartelization politiacal parties became clearer in the lead up to the elections in which party institutions had become the arena of conspiracy between party regimes and local ruling candidates or local power.
\end{abstract}

Key Words: Local Election, Local Actors, Political Patronage, Mining Bosses, South Kalimantan. 


\section{Introduction:}

Indonesia is well known as one of the countries that have abundant natural resource potential spread all over the country. One province with natural resources. especially coal mining resources is the Province of South Kalimantan, until now a mainstay of regional revenue in moving the development economy, although not yet reflect and bring on the social welfare and economic community. Constitutionally, natural resources are controlled and managed by the state and destined for the welfare of all people. This is as written in the state constitution so that the state must be present to manage this rich natural resource wisely and fairly not only to be observed by a handful of people or groups close to the ruler but for the public good. The world of the mining industry is a world full of conflict, intimidation, human rights abuses, and social economic poverty to local people, especially for people living in mining sites as an inevitable reality in the world of extractive industries in the era of global economi. The world extractive industry is an economic activity that often creates problems and conflicts between local communities and mining companies that lead to suffering and sadness.

The mining industry is the logic that pursue the accumulation of profits as much as it often does not pay attention to the interests of others or local communities that are in the mining area. Meanwhile, the state is often absent or in favor of the interests of the people and more defends the interests of the company with a number of policy policies, licenses, and protection provided by the state. A number of empirical facts show that in some rich countries in natural resource it is not directly proportional to economic growth and social welfare paying to its citizens, as is the case in Indonesia where there is no social conflict and intimidation between local people and mining companies. The greedy behavior of uncontrolled mining predators has devastated the structure of the natural environment with all other impacts incurred without regard to the existence of local communities living in mining areas.

This fact occurs in some areas of South Kalimantan Province, Indonesia, where local communities have long lived for generations, from generation to generation. The presence of the mining industry has devastated their social and economic life. They are powerless against a mining regime supported by security forces such as police and soldiers who always secure mining activities. Their villages have been bare because forests and the environment have been displaced by operating mining machinery. This phenomenon occurred in several regency in South Kalimantan Province since the mining industry operated in 1980 until today. Therefore, a sense of inadequacy and oppression often occurs and leads to social conflict between local people and the company (Luthfi Fatah, 2007). Unfortunately, in some cases of social conflicts some mining areas as described by Tadjoeddin (2007) in his works, A Future Resource Curce in Indonesia: The Political Economy of Natural Resources, Conflict and Development, the state or local government is often more pro-corporate than defending the interests of local communities. The collective accumulation structured by the feeling of injustice often generates conflict and violence between local communities and companies

\section{Theoretical Perspective}

Studies of countries with abundant natural resources but no significant relevance to the socio-economic well-being of their citizens have been largely undertaken by some scholars see the curse of natural resources as caused by rent seeking behaviors that increase corrupt practices which in turn reduce economic growth (Bardhan, 2011), On the one hand, thereis evidence of a negative marginal impact of natural resources on economic performance, Sachs and Warner (2001). Recent empirical evidence has thus started to take into account coefficient heterogeneity in order to determine whether there are conditions under which the resource curse can be avoided. In their works (Sachs and Warner (2001) provide evidence of a negative 
impact of natural resources on growth and find no support for the idea that geographic features or climate explain the resource curse (Andrew, 2007).

Elinor Ostrom (1990) is one of the experts who was named as one of the winners of the Nobel Prize in economics. Ostrom's success in winning the Nobel prize is closely related to the shared resource management issues he has carefully developed and developed. In essence, Ostrom pointed out that the collective ownership should not end with a tragedy such as that described by Hardin that when a resource is not taken over by the government or controlled by the government it can result in the destruction of that resource or the tragedy of the common, Hardin (1968). Ostrom argues that a commu nity that utilizes the resources of a multiplicity can agree to mingle it well. They can build con- servations, watch over, and sanction each other on the disbursement by fellow members. Thus, the solution to the problem of the tragedy of the commons is not necessarily a privatization (in the sense of being individual or entrepreneurial) or the application of the state tax system. Co-benefits that leverage resources together are reliable and fully accountable for managing those resources. This is commonly called commmunity-based resource management or community resource management.

The theoretical perspectives mentioned above, built a leading argument that in the era of political decentralization after the fall of the Soeharto government, the current management of natural resources all policies and regulations are dependent on the authority of the local government. If during the reign of the Soehato regime, the management of natural resources was heavily controlled by the business cronies and Suharto's family. Similarly, in the current era of decentralization and regional autonomy, natural resource management is also heavily influenced by business cronies and local ruling success teams that position themselves as patron-business and political clients as a form of political reward as a result of the electoral process district head. Meanwhile, the people as spectators alone or become victims of a business and political conspiracy between local authorities and mine entrepreneurs.

In decentralization era are introduced of natural resource management is dominantly controlled by the local regulation is more determined by local government. The decentralization and local autonomy was initially assumed to provide hope or expectation for the local to improve the welfare, justice, quality of human resources, especially for local with rich natural resources. But the fact is not so. Unfortunately, behind the issue of decentralization and local autonom, it has made the arena of local rulers, local actors and interest groups taking natural resources to build a networks of conspiracy, corruption, mining mafia through policy regulations, such as granting mining business permits to mining entrepreneurs or brokers mine (As'ad, 2015, 2017, Kholid, 2009).

Since late-1998, Indonesia has undergone a process of rapid and far-reaching decentralisation. With this process, considerable degrees of administrative and regulatory authority have been transferred from the national government in Jakarta to the country's provincial and district governments. This transfer of authority has occurred across broad segments of the nation's economy and has sharply redefined the roles and responsibilities of government agencies at each level of the nation's administrative structure. With the locus of decision-making shifting decisively away from the national government, Indonesia's ongoing decentralisation process marks a dramatic break from the highly-centralized system of governance that characterized Suharto's New Order regime during the period 1966-1998. To a significant extent, the process of decentralisation now occurring in Indonesia has been driven by the demands of provincial and district governments whose jurisdictions are rich in timber, petroleum, and other natural resources. Officials from resource-rich regions have long complained that the vast majority of the benefits from these assets have flowed away from their 
regions to the national government and to private sector companies closely associated with decision-makers in Jakarta.

In many parts of Indonesia, provincial and district officials acting in the spirit of decentralization have instituted reforms that extend well beyond the authority granted to them under the national government decentralisation laws and regulations. Indeed, the formal decentralisation process has been driven, to a significant degree, not by policy decisions made at the national level but, rather, by decisions made by provincial and district level actors. This process has often been ad hoc in nature, with national policymakers frequently finding themselves in the position of having to react to fast-moving changes that have occurred in the provinces and districts. Far from being a well-planned and carefully-managed exercise in bureaucratic reorganization, the implementation of regional autonomy in Indonesia has been characterized by intense struggles among the different levels of government, each of which represents a competing set of political and economic interests. In this way, regional autonomy has stretched well beyond the formal decentralisation of administrative and regulatory authority; in practice, it also involves a significant, if largely informal and unplanned, devolution of power from the national government to its provincial and district-level counterparts (McCarthy, 2004).

The underlying logic of decentralization is that democratic (or locally accountable) local institutions can better discern and are more likely to respond to local needs and aspirations because they have better access to information due to their close proximity and are more easily held accountable to local populations. Downward accountability of local authoritiesaccountability to local populations-is the central mechanism in this formula. In brief, effective decentralization is defined by an inclusive local process under local authorities empowered with discretionary decisions over resources that are relevant to local people. It is an institutionalized form of community participation.

Decentralisation policy is a programs aim to increase the ability of local civil society to monitor and pressure local government. However, what happens when the analytical categories that the turn to civil society assumes and on which the prospect of successful decentralisation depends are absent? According to McCarthy in his works Local Voice in Shifting Modes of Decentralised Resource Control in Central Kalimantan, Indonesia (2007), how decentralisation and the subsequent recentralisation affected the exercise of public powers over nature in the local domain in Central Kalimantan.

Decentralisation in Indonesia involved a struggle over resources that reveals a particular trajectory of politico-legal change. In common with other areas subject to decentralisation reforms, elites undoubtedly benefited disproportionately in the course of these struggles. Yet, rather than seeing this as another case of elite capture that these changes can more readily be understood in terms of a swing between two well established modes of resource control that are both connected and competing. Before decentralisation, localised or decentralised modes of exchange and accommodation were well established but less salient. During the high season of regional autonomy these modes became more autonomous of the previously dominant centralised mode of resource control.

The late New Order system of governance that operated before regional autonomy has been analysed in terms of horizontal and vertically integrated networks of power and interest largely financed with extralegal revenues, including those derived from the timber sector.Under this system powerful politico-bureaucrats pursued entrepreneurial activities and extracted rents where possible, either for self enrichment, to command the loyalty of others both within and outside the pecking orders, and/or to sustain the political interests of the institutions in which they were embedded. For local people to become enfranchised as citizens rather than remaining dependent subjects, their local representatives require a domain of secure 
discretionary powers and rights. This domain of secure rights must be established in law and protected through representation and recourse (McCarthy, 2007)

Some issues that emerge concerning three basic elements of decentralizationaccountability, discretionary power, and security - as well as other key reforms that can help activists and policy makers bring out the positive aspects of decentralizations involving natural resources while minimizing negative effects. Legislating and implementing decentralization are the first steps. But even where secure decentralization has been implemented, support and accompanying measures from central govern- ment and others are needed to assure that natural resources are not over exploited, that equity is not compromised, and that legislation and implementation do not work against each other.

Some of these efforts include minimum environmental standards and alleviating poverty, as well as accompanying measures for civic education and conflict mediation. Central government must play a key role in advancing reforms needed to achieve effective decentralization. In practice, an end-point of decentralization reform is never reached, since reform entails an ongoing political struggle between local and central interests. Central ministries are targeting and allocating power to a variety of local institutions in the name of decentralization. better serve local needs ( Robot, 1998).

After briefly describing the politics of decentralization that the policy is increasingly providing wider space and opportunities for local authorities to make policies or regulations relating to the control of natural resources. So that, the other side that natural resource management is not only seen in the context of the pursuit of economic gain only. In the case of natural resource management in South Kalimantan Province, natural resource, especially mining industry is inseparable from the growing interest of political interest, especially related to the issue of regional head election or democratic party event. Mining actors or predators play the mine issue in the context of political interests to seize local power through transactional politics among local political actors and mining predators. Mining issues entering in the political game arena where many mining industries promise economic income sources to finance political activities, especially at the time of the election of the local head election or legislative members election

As it is known in that economic development activities tend to focus on the exploitation of natural resources as happened in the Province South Kalimantan to improve people's lives without taking any real action in conserving these raw materials. This uncontrolled exploitation has eclipsed the environment and impoverishment is not realized by the stakeholders who use and have access to these natural resources. The Common Property Regime here should be all natural resources used by the public and open source where everyone is entitled to use it to ensure continuity of the need for satisfying needs. It is often open-ended, where everyone is free to use it or open access where nature is non-existent and as if it can not be exhausted. As a result of that open access, every individual who utilizes these resources tends to devote him as much as possible to the extent possible regardless of its sustainability. On the other hand, each individual is reluctant to maintain the preservation of the resource on the grounds that it is useless to maintain sustainability if others do not or otherwise, and instead exploit it for his own benefit.

The damaged environment due to the influence of accumulation and exploit uncontrolled natural resources. The development of the population that is not comparable with the availability of natural resources will make the earth is getting worse into a global environmental disaster. This is a social burden because it will ultimately be borne by all layers of society and order. A paradigm shift in the management of the economy, natural resources 
and environment in which these three things are incorporated into a common system. In this environment the living environment is seen as a major asset in the economic process. The environment provides life support systems to maintain human existence. To overcome the depreciation process of environmental assets not only for the sake of conservation and environmental conservation but for the benefit of long-term economic activities to meet the human needs of both present and future generations (Ross, 2007).

As a result every individual is trying to become a free rider who utilizes natural resources A resource that benefits a group of people, but which provides diminished benefits toeveryone if each individual pursues his or her own self-interest. The value of a common pool resource can be reduced through overuse because the supply of the resource is notunlimited, and using more than can be replenished can result in scarcity. Natural resources are only beneficial to a particular group or a few people. But this resource is not always eternal because the number is only limited. If each person or group only prioritizes its own interests then what will happen is the seizure of resources and will lead to scarcity and generate reduction of benefits for each person or group. Because in this competition the resources must be divided into the respective actors.

\section{Locating the Research Empirically: South Kalimantan Provinsi as a Setting}

The South Kalimantan Province as well knowen is second biggest coal producing in Indonesia. Yet management of these rich resource is taking place in a way that does not accord with good governance practices. The local regulations produced to regulate the industry tend to reflect the political and economic interests of local political and econmic elites. When those regulations are then implemented, the beneficiaries are the investors rather than members of local communities around the mining sites or the public at large.

The rich resources of the province have yet to lead to improved living stadards or welfare for the population of the province. On the contrary, they have led to marginalization of local people from their traditional livelihoods, and massive environmental destruction. (For a comparative discussion of natural resorces extraction, (see Jefferey D. Sachs and Joseph E. Stigliz, 2007, Escaping The Resource Curse). If these resources were better managed in accordance with good governance principles, they should be able to produce improved welfare in terms of education, health and infrastructure development. Yet the evaluation made by the local environmental organisation, Walhi, is bleak: With] coal mines still the primadonna of the South Kalimantan economy, the extraction of coal in the province can be compared to the people digging their own grave.

The intrusion of political and economic interests into the management of the sector, is seen for example in the role played by bargaining between economic and political elites around the time of direct local elections (pilkada). Mine owners are regularly the major donors to candidates running for political office in the province. This phenomenon has become arguably the most striking feature of local politics in South Kalimantan in the era since the reformasi process and decentraliszation policies began in Indonesia more than a decade ago.

Meanwhile, the local community faces a situation of highly assymetrical power relations, lacking the capacity or the political access to become involved in the management of the natural resources sector. As a result, there are often episodes of community resistance to mining operations, including in the form of demonstrations, or most recently in 2012 of a blockade of access to river transportation for the mines. These forms of resistance are motivated by a sense of injustice on the part of local people, both concerning their relations with the companies and the failure of corporate responsiblity, as well concerning the division of royalties between Jakarta and the regions. 
Of the 13 districts (kabupaten) and muncipalities (kota) in South Kalimantan, more than half produce coal. But infrascture and economic development, as well as social welfare are lagging, as reflected in the provinces's HDI ranking of 26 out of the 34 provinces of Indonesia. It turns out that the rich natural resources of the province have not provided a significant contribution to the local community. In fact, it can be said that the province is experiencing a resource curse whereby, resource wealth promotes the ascendance of the predatory state over the developmental state, either by actively encouraging the former through corruption related to resource rents, or by undermining the latter when revenue flows associated with resource extraction reduce the efficiency of policy and administration.

\section{Mines Between to Increase Local Revenues and Conflict Interest}

Collaboration of interests bewteen state and private actors usually focus on the issuing of Izin Usaha Pertambangan (mining enterprise licenses) both before and after local elections. Local politicians often issue these licenses and at the same time seek donations from mining bosses in order to fund the very high cost of their political campaigns. Almost all bupati (district heads) in coal rich districts - such as Tanah Bumbu, Banjar, Rantau, Balangan, Tanah Laut are backed by coal mining interests.

In addition to the large-scale legal mines, there is also widespread illegal mining in the province, which is allowed to proceed by security forces, because the illegal mines also produce a steady stream of income for government officials (Walhi Kalsel 2009). This arrangement has already lasted many years and is very difficult to eradicate given the large number of key government and security officials who are involved. The widespread nature of illegal mining is accelerating environmental destruction in the province, for example, in the forms of widespread flooding that happens around the locations of mines, or in the form of changes to the soil structure as a result of the the disposal of mine waste through the river system. The term illegal mining was used during the New Order peroid to refer to mining activities, typically small-scale operations using traditional equipment, undertaken without a licence from the government. In the post-Soeharto era, two new terms related to illegal mining are officially used: penambangan tanpa ijin or peti (mining without a licence) and tambang rakyat or rakyat penambang (people's miners). The latter term refers to small-scale mining activity carried out by local people using traditional equipment on their own land, but without a government licence.

It is difficult to determine the exact of illegal mining in Indonesia. Illegal mining is highly organised activity, opten with close links to the criminal underworld. Each mining site is controlled by a group of preman extortionists or standover criminals) headed by a "boss" or mine leader. The hire miners to work the site with number of miners varying depening on the size of the area they control. The preman compete with other gangs for control of the best mining sites, and must protect their own mine from theft by other gangs. The preman also deal with the local authorities and the police, and ensure that the miners do not tell the general public about the mining operation. (For a comparative discussion of illegal mining in West Sumatra, see Erman, 2005). In social terms, one negative effect of the mining boom has been a rise of wasteful consumption in local communities, as well as spread of social ills such as prostitution around mine sites and negative health effects such as respiratory illnesses.

The exploitation of natural resources has not been without problems. portray that natural resources management in Indonesia is loaded conflict. The extraction of natural resources generetes externalities manifested in environmental problems that eventually brings about the conflict. This conflict has long time dreadful records. From 1980s, there have been 
latent conflict between local communities and business caused by land issues. Dayak Benuaq and Tonyoi, a traditional community in East Kalimantan oppose PT. Kelian Equatorial Mining digging gold in their areas. Dayak Siang, Murung and Bakumpai, a conservative community in central Kalimantan have tried to keep their traditional land rights from the illegal occupancy of PT. Indomuro Kencana (Aurora Gold) which is digging gold on their land. Meanwhile, a traditional community in Paser Regency, East Kalimantan, has been trying to retain its rights over traditonal land from PT. Kideco Jaya. The other case, Amungme, an indigenous tribe in Papua, has been confronting PT. Freeport Indonesia for several years to maintain its traditional rights (Maemunah, 2012).

The conflict arise because the Indonesian goverment cannot enforce a comprehensive system to respond the externalities. The agreement of mining corporation to excavate is signed between the company and cntral government. Meanwhile the ones that get the externalities, local government and local people are not involved in the contract. In Many cases, the corporation perceives that it has complied with central government. On the other side, local government and local people who suffer the operation of corporation consider that they may get compensation.

All of this is happening as a result of the failure of good corporate governance. The key principles of good governance including 1) accountability 2) transparency 3) participation 4) law enforcement. To take one of these principles as an example, transparency, there is very limited public knowledge about the annual earnings of the various mines. Indeed, even officials of the provincial office of the Department of Mining say that they do not know the exact production figures for the province on an annual basis, both because they believe many of the reports they receive from the districts are invalid, and because they are only able to make a rough estimate of 1.2 million tonnes per year of production for those large mines whose licenses are issued by the national agency (interview with provincial head of the Mining Agency, December 2017).

This situation not only reflects poor coordination between the different levels of government, it also makes it impossible for provincial officials to know whether royalties are being paid at rates in accordance with prevailing regulations to the various levels of government. For instance, 2.7 trillion rupiah per year is paid each year to the province from royalties raised from the mines whose licenses are issued by the central government in Jakarta, with part of that income then redistributed to the districts where the mines are located. After political lobbying by the provincial government in Jakarta, this amount was increased to 2.7 trillion rupiah in 2013 (source: interview with the head of Commission III of the provincial legislature, February 2017), in part as a result to the political controversy and protests that had been building in the province. Despite the increase, the various revenue flows involved are still entirely lacking in transparency: provincial officials know neither what the companies profits are or what share Jakarta takes.

Decentralisation has opened the political opportunity structure for local elites to use government insitutions and regulations to extract natural resources for their own benefits. In doing so, they typically argue that their goal is to increase local revenues (Pendapatan Asli Daerah, PAD) in order to fund regional development projects. For instance, in the district of Tanah Bumbu, more than $40 \%$ of PAD is obtained from the mining industry. However, this increase of local revenues has not produced significantly improved infrastructure or economic conditions at the local level. The district of Tanah Bumbu provides a good example of the negative effects of the mining industry on local governance.

With 251 mine licenses issued by the bupati (district head), the district is one of the highest intensity mining districts in the province. The industry has produced not only formal revenues for the local government, but also informal revenue streams for individual officials 
in the local government and the security apparatus. For each barge that leaves the district packed with coal (and there is an average monthly frequency of up to 80 barges passing down the Barito river to their rendevous points with cargo ships at sea), payments of hundreds of millions of rupiah are made by the mining companies to local officials.

These payments, which the companies budget as 'tactical funds', are then divided among local officials such as subdistrict police chiefs, subdistrict mlitary chiefs, subdistrict civil government heads, harbourmasters, marine police commanders, navy officers and the relevant police, army and civilian government officials at the district level, with it being widely undestood that payments are made to provincial and central government officials as well. The amounts paid to the individuals vary according to their seniority and function. For example, it has been estimated that the subdistrict head in Setui can receive "hot money" of approximately 40 million rupiah (approximately \$4,200), more than ten times his basic wage. Other officials seek funds from the mining industry in other ways, for example by supplying fuel to the companies, by acting as brokers between them and buyers, or by supplying security services at mining sites. As a result of such practies, over the last decade many officials in the district have been able to enrich themsleves.

\section{The Source of the Problem: Mining Licenses (IUP)}

The critical point in the regulation of mining - and the core site of political transactions between political and business actors - is in the issuing of Mining Company Licenses (Izin Usaha Pertambangan, IUP). The national ministry of minerals and resources is responsible for issuing licensese for mines that cross provincial boundaries or cross several district boundaries and has issued 27 such licenses in South Kalimantan (one example is the license for PT Adaro in the districts of Tabalong and Balangan, PT Arutmin Indonesia in Kota Baru and Tanah Bumbu, owned by the famous Indonesian mining magnate and politician, Aburizal Bakrie). Over 600 licenses have been issued by the various bupati (district heads), with the largest number being issued in the district of Tanah Bumbu with over 200.

The environmental organisaton has identified systematic corruption around the issuing of IUP. For example, many IUP are issued without the prior issuance of a special license for the use of protected forest land by the regional office of the Forestry Ministry, or prior to the carrying out of an environmental impact assessment. Another chronic problem is the issuing of mining licenses in areas that are designated for other purposes in regional regulations on spatial planning, such community farming, oil palm plantations, or forestry operations. Indeed, the combined total of land allocated for mining, forestry and plantation in the province amounts to 3.1 million hectares, not far short of the total land area of South Kalimantan, 3.7 million hectares.

These licenses are typically issued in a way that is highly politicised. Recipients are very often those who have personal connections with the district head. They may be family members (for example, more than fifty of the 200 in Tanah Bumbu are held by relatives of the bupati, Zairullah Azhar). Recipients are often also members of the so-called 'success teams" that are formed to support and fund the election campaigns of district head candidates. The transaction is typically simple: in exchange for funding for the campaign, the donor is rewarded with a mining license, and from this arrangement arises ongoing enmeshment of political and business interests in the district concerned. Political office is effectively captured by the mining boss.

One famous example in South Kalimantan is the case of Zairullah Azhar himself. $\mathrm{H}$ Samsuddin (usually known as Haji Isam) was already a wealthy businessman (mostly with 
timber interests before the election of Zairullah. After he (along with several other businessmen) sponsored Zairullah's election his mining operations expanded dramatically in the district. He later sponsored Zairullah's attempt to run as governor in the 2010 gubernatorial elections, at great cost (Zairullah lost to Rudy Ariffin, whose main sponsor was Haji Ijai, another famous local coal mining magnate based in Binuang in the district of Tapin). Zairullah's successor as district head, Madani H. Maming was himself previously a coal miner. His wealth originated with his father, who was a village head in an area rich in coal. Previous to becoming district head, he was a member of the district legislature, a strategic position from which he could influence local economic policy. He defeated the elder brother of Zairullah in the 2011 elections in the district, in what was effectively a contest between rival mining dinasties.

This predatory political economy has produced signficant environmental and other costs in the district. For example, four years ago a massive flood occurred in Tanah Bumbu, destroying a number of major bridges and causing loss of life, as a result of deforestation linked to the mining industry (this flooding was part of a wider wave of floods, with 21 floods recorded in 2009, inundating over 15.000 hectares of rice fields, and affecting 11 of the province's 13 districts; sources, WALHI, 2011). Another serious problem in the district is the unregulated nature of mining waste disposal which has caused widespred water pollution with heavy metals and causing skin ailments, among other problems. Several of the mines in the district are located very close to villages. For example, in the subdistrict of Satui mining takes place along the side of a main road; a local cemetry has even been dug up to make way for the excavations. Satui has become akin to a mining town in the midst of what was once a quiet rural district. The infrastructure is reasonably advanced in this town - e.g. education and health centres - but it is one of the very few places in South Kalimantan to experience such benefits, while most of the villages in the district concerned have experienced significant economic marginalisation.

\section{Formulation of Local Regulation on Post-Mining Land Reclamation}

There are three critical domains in governance: 1) government 2) the corporate sector and 3) civil society. In the governance of the mining sector in South Kalimantan, the relations between these three domains is imbalanced. The government is largely captured by the corporate sector and is unable to play the control function role it should be able to exercise with regards to the private sector. Civil society is marginalised in the governance process though local NGOs, and the mass media are significant local actors - they have over the last decade been little not involved in the process of formulating and implementating management over the coal sector. However, in recent times, especially since 2012, the beginnings of a change of public mood have been visible. The widespread environmental and social damage caused by mining has been gaining increasing publicity and has led to attempts to begin to introduce regulations to deal with some of the worst aspects of the industry.

In 2012-13, the provincial executive government and DPRD (provincial legislature) were engaged in a long process of negotiation to produce a new local regulation requiring coal companies to rehabilitate land after the closure of their mines. This is widely agreed as being an urgent need in the province, with many local companies having abandoned their mines without cleaning up the sites, leaving huge holes in the ground that form into lakes, ponds and rivers. The result is ongoing environmental damage, localised flooding, malaria and other water-borne diseases, as well as other negative effects. The coal of reclamation is to rehabilitate these sites to return them to productive use for local communities, in the form of farm land.

As a result of public pressure on the issue, in 2012 a group of legislators in the DPRD's Commission III (the commission responsible for mining policy) established a special 
commmittee (panitia khusus pansus) to draft a bill dealing with the matter. Public hearings were arranged, with local academics, experts, NGO activists and the mass media invited to present their input into the drafting process. This was a very costly process, with the DPRD members involved three times going on study visits to other mining provinces in Indonesia (for example, they visited the PT Bukit Asam operations in South Sumatra, November 2012).

Over forty mining companies were invited to present their views on the bill. They agreed to implement the regulation consistently, despite the impost this imposed on them and the potential sanctions (which could go right up to revocation of mining licenses). The critical article in the draft regulation requires miners to carry out the reclamation process and thus operate in a more sustainable manner. While during the drafting process, the interests of miners were influential, there was an attempt on the part of legislators to represent a wider public interest and to avoid negative impacts of mining on local communities.

Despite the passage of this regulation, there are still few reasons to be optimistic about the eventual outcome. The problem is that there has been a bad track record in law enforcement. For example, in the leadup to the 2010 gubernatorial election, the governor of the province, Rudy Ariffin, in cooperation with the provincial parliament issued a regional regulation on Mining and Highway Transportation (Perda No. 3 2008) that prohibited the use of public highways by mining trucks. These trucks had been causing a great nuisance to other road users. Early on, the new rule was implemented effectively, greatly reducing travel time for citizens who were using roads that were now far less congested.

However, as time passed, implementation became less effective, with mining trucks increasingly using these roads, especially at night time, faciliated by paying illegal fees to officials in the monitoring posts that were set up along the roads to enforce the new rules. The roads which had been repaired, rapidly became damaged once again by the passage of heavy mining trucks. With such experiences behind them, many people in South Kalimantan now believe that the politically connected mining companies will be able to avoid obeying the letter of the new reclamation regulation. In conditions in which illegality has become a norm of corporate behavior, it is unlikely that improved regulations will alone improve the situation

The business and political relationships in the mining industry in South Kalimantan Province are inseparable as two sides of the coin. The issue of the mining has always been political marketing as a strategy to make bergaining position or networks business and political patronage. This can not be avoided because after the Soeharto's government, the national political dynamics became more liberal, pragmatic, and the more capitalistic democratic process which of course required a high cost. Therefore, at present almost all the regional authorities in South Kalimantan Province are people who have a background of entrepreneurs, especially coal mine businessmen. They have the capital or the power of money to finance a transactional, capitalistic democracy. Similarly, almost the heads of political parties or administrators of political parties are entrepreneurs or backgrounds of coal mining businessmen. Usually the rulers run for regional ruling candidates or sponsor political funds for candidates who fight in local elections (As'ad, 2016 2017, Aspinall and As'ad, 2015, Aspinall and As'ad, 2016).

As a result, many local officials are caught for abusing power, elite capture corruption and rent-seeking practices using for seeking economic gain and political power, even if they violate the rules. The extremely loose use of power and regulations has impacted the destruction and impoverishment of the local communities as a result of the conversion of forest to mine. Land use transfer from forest to mining area becomes an economic opinion for 
regional heads and entrepreneurs to make a profit regardless of the socio-economic presence of local people.

As the main leading argument of this paper that rich of natural resources, particularly in the coal mining sector have not been directly proportional to the improvement of economic and social justice for communities despite the decades-long exploitation of coal mines. The policy of decentralization has created opportunities for local actors and mine predators to utilize decentralized mine resource management by building conspiracy networks and local officials or political elites who have positions in local government and legislative members as well as with security forces such as police and soldiers.

As for the networks pattern of conspiracy between local officials and mining entrepreneurs through the expenditure of mining business permits: First, licensing issued without consideration of the spatial layout or the carrying capacity of the natural environment causing many conflicts between citizens with mining companies and massive clearance of protected forest areas. Second, usually the issuing permit is issued ahead of the election of regional head (regent and gobernur) as a strategy to strengthen the mutually beneficial network of business patronage and transactional politics. Third, the overlapping of permits that reach the thousands is allowed to last protracted and potentially become a bargaining event between the ruler and the entrepreneur. Fourth, the abuses of lawlessness in major cases of public interest that resulted in state losses arising from corruption and mafia practices in the mining sector.

In the mining business license expenditure requires a lot of funds. This is an opportunity to get funds for local officials authorized to issue mining permits. The province of South Kalimantan is well known with many mining permits issued by several local heads. Such practices have long been taking place, especially since decentralization and regional autonomy have been implemented since local governments have wide-ranging regulation policies that are barely controlled by the public because of their under cover nature. The management of natural resources that has been going on for so long is managed in mafia and sermpangan ways does not put forward the principles of accountability, transparency, and justice. Not implementing good governance coal mining practices. But the opposite is seen is the management of bad governance coal mining practices that do not give a sense of justice for the public. The practice of corruption, mining mafia, and abuse of power has led to victim of policy for local communities and environmental degradation and has become a vicious circle that is difficult to disentangle because there is no political will from stakeholders to implement transparent and accountable mining policies, but what happens is the conspiracy and greed of local (As'ad, 2016).

As a consequence of the misconduct of law enforcement and acts against breaches of rules for mining companies that are unemployed, there is often resistance from local communities to the presence of mining companies in their areas. No wonder if all this time the mining industry only enjoyed the results by mining predators. Namely entrepreneurs, political elites, business patrons of local authorities as described by a number of local communities. Local communities only feel the bad impact but do not feel socio-economic prosperity. Just look at the words of some local communities that the mining industry that has been operating since dozens of resistant, our village no change anything socio-economic and infrastructure development but it is the destruction of the environment, marginalsasi culturally and tradition gradually began to become extinct due to greed of corporatocracy.

The presence of mining companies in some regions or districts in South Kalimantan Province is really just a curse, and not a blessing. They are driven from their hometown, which since their generations settled in their village. They have to flee for new livelihoods and build new villages. They can not survive being pressured by exploitation of the mining industry. 
They lost their independence and human values. Loss of economic, cultural, and social resources as a legacy from their ancestors gradually wiped out local wisdom and local knowledge that became values system to drives their lives has been destroyed by the mining machinery industry. Local communities who defend their rights to the land they own are arrested and imprisoned for being accused of being provocateurs and considered to be company activities. The government that is supposed to protect of the local communities is more defending the interests of the company. Political corporatocracism, such as greed and in difference to the environment and the existence of local communities as a serious problem in mining areas in South Kalimantan Province as well mining areas in other provinces in Indonesia. The greed of the company is gaining the greatest of these limitations of natural resources into concern for those who care about the environment and the existence of local communities.

In the decentralization a, the mode of conspiracy between local government officials and corporations can be seen from the process of issuing hundreds of mining permits. The indication can be seen from several things: First, the permit issued without considering the spatial layout of the territory, or the carrying capacity of the natural environment causing many conflicts between citizens with mining companies and massive clearance of protected forest areas. Second, the issued permits are issued ahead of the district elections, as well as the gubernatorial election, as happened in South Kalimantan. Third, the overlapping of permits that reach the thousands is allowed to drag on and potentially become a bargaining event for money between the rulers and businessmen. Fourth, the abuses of lawlessness in major cases of public interest resulting in state losses arising from corrupt and mafia practices in the mining sector continue.

When viewed from the economic aspect, mining industry in terms of royalty is not too significant for local government. This can be seen from the royalty sharing system. The division of mine royalty, the central government gets 20 percent, while the provincial government is 16 percent, the district government as a mine-producing region gets only 32 percent. For the regions (districts), which do not have mining mining areas, such as Banjarmasin city, Barito Kuala regency gets 32 percent. Therefore, the largest contribution is from third party donations that contribute to the local government of Tanah Bumbu Regency as the original revenue of the region. As an illustration, in 2010, revenue from third party donations reached 60 billion, in 2011, reaching 90 billion, in 2012, 120 billion, in 2013, 200 billion. In 2014, 180 billion declines as the global coal market declines. According to Mardani $\mathrm{H}$ Maming, Regent of Tanah Bumbu District, the third-party donation is intended to finance the local government's non-permanent employees, amounting to about 4,000 people, to pay for free schooling until the age of 12, free medical treatment for poor citizens, Teachers who number approximately 1700 people. Also intended for socio-economic empowerment of the community.

The involvement of a number of mining companies in illegal mining activities protected by unscrupulous security personnel. Illegal mining activities can not be eliminated. Precisely illegal mining has provided benefits to the parties involved in this dark activity. Therefore, the occurrence of neglect of illegal mining has spawned a number of people into the new rich of such haram practices As the decline in mining business in recent years has affected illegal miningactivities. In 1996, Gusti Hasan Aman, Governor of South Kalimantan Province at that time formed a team to control coal mining based on Governor's Decree no. 17 of 1996. The team carried out repressive actions for 3 months (March - May 1996), but after that no followup. In 1997, illegal mining began to expand to Hulu Sungai Tengah and Hulu Sungai Selatan. 
In 1998, illegal mining has spread to Hulu Sungai Utara, Hulu Sungai Tengah, Hulu Sungai Selatan, Banjar, Tanah Laut, Tanah Bumbu and Kotabaru Regencies. Illegal mining activities have entered mining areas of PT. Adaro Indonesia, PT. Mantimin Coal Mining, PT. Arutmin Indonesia, PT. Antang Gunung Meratus, PT. Chung Hua OMD, The Governor of South Kalimantan Province at that time submitted a request to the Director General of General Mining to temporarily shut down the petition for the mining authority.

In 2008, Rudy Ariffin, Governor of South Kalimantan issued a Regional Regulation on the prohibition of the use of public roads for coal mines and iron ore and plantations. This regional regulation was effectively implemented in 2009 until now, however illegal mining still exist in secret. This is as expressed by the Head of South Kalimantan Province Mining Service, that illegal mining can be classified into 4 criteria: First, mining activities not equipped with permits. The two holders of mining business licenses that engage in mining activities outside the mining permit area. Third, holders of mining permits conduct mining activities before exploitation permits are issued. Fourth give letter to other party for outside mining area.

\section{Local Election and Illegal Mining: As Network of Conspiracy of Mining Predators}

In this section of the paper we will describe the network patterns of the mine preadators. One of the arenas of building a conspiracy network of mining predators is at the time of the regional head election. The involvement of mine predators behind democratic capitalization, acting as a political broker or supporting financier, as well as a strategy of building patronage with potential rulers area. The capitalization of democracy, the local political landscape in South Kalimantan Province, mining issues always color political marketing among the actors who fought in the democratic event (election). The involvement of mining entrepreneurs behind the capitalization of local elections becomes the arena of conspiracy and economic and political patronage. Conspiracy and economic and political patronage have established a hidden interest for a predatory monopoly of mine management.

It is a reflection of economic scarcity that seeks to accumulate local economic resources and is controlled by a handful of people because it has closeness with officials who provide protection. In this section of the paper it is also argued that the predatory group has made the mine issue as the arena of conspiracy in the local election process. After the end of Soeharto's rule at this moment the mines power has shifted from central predators to regional predators or in local elite capture in line with decentralization and regional autonomy policies. In the local political landscape in South Kalimantan Province, every political event, mining issues becomes trending topics and political marketing amidst the political pragmatism of society.

According to Taufik Arbain, a lecturer and observer of local politics from the Faculty of Social and Political Sciences of Lambung Mangkurat University Banjarmasin said that: "Behind political political event. For example the election of regents, governors, and election of legislative members, is always related to mining issues". "The election as a process of democratization has been taken hostage by the power of capital. Local actors and mine predators work together to build strength to support local ruling candidates and position themselves as the playing makers who can manage the pattern of political raids and rhythms in the province of South Kalimantan. It is not unusual that post-elections of the playing makers position themselves in government as a shadow government and at the same time become chronic business and political patronage of the master of monopolizing economic resources, especially mining business, and regional infrastructure development projects as a form of political repayment", (interview in Banjarmasin, January 15, 2017). 
According to Samsul Daulah, a non-govermental organization (NGO) activist said "that most of the elected regional authorities in the election behind him are mining entrepreneurs or local rulers of mining entrepreneurs and have financial support from mine business operators with mining business connections. This fact is designed by the local capitalist groups, even did not rule out also get support from the capitalist funds in Jakarta. Therefore, political capitalization and pragmatism has led people into political play (money politics) or vote buying played by actors in local elections to influence citizens. Do not be surprised if election gave birth to local rulers having predatory oligarchs amid democratization issues after the fall of the regime authoritarian of Soeharto's New Order". (Interview in Banjarmasin, Januari, 20, 2017).

Another clash of conspiracy models of mining predators in addition to being the regional head election arena for the construction of conspiracy networks is the process of abandoning illegal mining activities. Various factors encourage illegal mining activities, among others, increased demand for coal, inactivity of license holders, lack of public legal awareness, ease of coal mining in the field. Illegal mining actors are the owners of capital, equipment owners (heavy equipment and transport), miners, mining containers. Illegal mining operation mode, which holds a mining operation permit to send a letter to a person involved in mining that mines outside the mining permit area, holds a mining license to sell a letter or certificate of origin of goods to illegal mining actors, holders of mining business licenses Outside the mining permit area and using self-made mailings. The location of illegal mining activities is carried out among others in the mining area of PT. Arutmin Indonesia located in Kintap, Asam-Asam, Satui, and Tanah Bumbu surrounding areas. Illegal mining activities also take place in Senakin area by PT. Jorong Barutama Greston, PT. Borneo Indobara, PD. Baramarta, PT. Kadya Caraka Mulia, PT. Tanjung Alam Jaya).

Another mode of illegal mining activity is also carried out by the mode: First, the company or individual who operates on community land that is not located concession area of mining business license. Secondly, companies with licenses that are still actively engaged in mining activities outside the concession area of a mining business license owned by the company. This is because coal that is outside the concession of the mining business license has more and more profitable coal potential than the existing coal potential in the mining concession concession area owned by the company. Third, illegal mining activities carried out by a company or person in the concession area of mining business permit have not been worked on or that have been worked on by the company by the owner of the mining business license.

Illegal mining activities are organized by individuals who are involved in illegal mining activities, from coordination of land to be mined, use of coal haul roads from mine sites to shelters or ports, and to the acquisition of certificates of origin. The sequence of activities also involves security personnel, landowners, village officials, employees of corporate security, holders of mining business licenses. According to the villagers of Bina Wara Kecamatan. Kusan Hulu, Tanah Bumbu District, I was involved in illegal mining activities in 2004. My activities are backed by security forces with the mode of providing information on the planned or scheduled joint raid by the police. Then in 2005 joined to work on a mine owned by the Regent Tanah Bumbu at that time. The Regent of Tanah Bumbu Regent has several mining concessions or mining business permits, such as located in Kusan Hulu and Kecamata Kuranji sub-districts. Mining rights are named Indoku mining power, Wijana mining power, and mining authority Hatiib Bara Makmur whose status overlaps with mining concession area of PT. Borneo Indo Bara.

As explained earlier that illegal mining activities are nothing new in the mining industry, but became crowded after an indication of the involvement of high security officials 
as protectors of illegal mining activities. This is a portrait of a vicious circle that is structured with the involvement of ranks of security forces, local officials, and other interest groups. Next, the other mode is to issue a mining permit without permission to borrow forest area. In the record of the South Kalimantan Provincial Environmental Forum, the mining concession has already covered approximately 1.8 million hectares or more than one third of the total area of South Kalimantan Province, 3.7 million hectares. Based on these data, it turns out many areas or mining concessions that violate the rules of legislation, such as in Kab. Tanah Bumbu which has the largest number of mining permits in South Kalimantan Province.

According to Berry Nahdiyan Furqon, former National Executive Director of the Forum for the Environment, "that regulations or policies regarding the suspension of illegal mining activities will not succeed unless accompanied by law enforcement or control of the relevant agencies. Unfortunately, precisely the law enforcement officers involved as an operator in cooperation with illegal actors mining. Do not expect this activity to be lost because it promises economically despite impacting the destruction of natural resources. I argue that both legal and illegal miners actually contribute to the destruction of natural resources. The same comment was also submitted by local residents of Kuranji District, Tanah Bumbu District, that illegal mining activities are difficult to eradicate because they are in a structured network involving various actors, especially law enforcement personnel. Yes, indeed in recent years illegal mining activities have declined as the mining business declines. But illegal mining activities are still often encountered in secret, especially at night. Illegal mining has seriously damaged the environment that is impossible to recover. Illegal mining activities as a source of economic income for the parties involved in the activities of the mafia. this is a conspiracy mode", (Interview in Banjarmasin, March 15, 2017).

The power of the state has been co-opted by the power of corporatism of the mine. The number of illegal mining activities has led to protests from residents as happened in Terang Bulan Village, Satuai Satui Sub-District, Tanah Bumbu District. Mining activities are only tens of meters away from the residents' settlements, thus disrupting and even endangering residents around the mine. The mining activity has been stopped but will operate again without any coordination with the community, especially the people in Perintis Desa Makmur Mulia Satuai District. Protests by Makmur Mulia residents against the company to stop mining activities adjacent to the settlement.

Besides being disturbed by the noise, residents are also worried that the illegal mining activity caused the landslide. Previously, residents had demanded the company, PT. Son Kencana Sakti to free their land from entering the mining area. PT. Putra Kencana Sakti as sub contractor of PT. Arutmin Indonesia who insisted on mining because it refers to the agreement ever made between citizens with the PT. Arutmin Indonesia as the holder of mining concession permit which has done land acquisition around the settlement, and given a guardrail fence is a radius of 500 meters. "We are working on the power of PT. Arutmin Indonesia through working contract with PT. Jhonlin Baratama, we will keep doing mining activities, except PT. West Jhonlin who stopped him ", explained the representative of PT. Kencana Sakti. Another comment from the Chairman of the Rukun Tetangga Perintis Desa Makmur said that local communities have the right to stop illegal mining activities because they have disturbed the residents' housing environment, such as noise, fear of landslide and dust pollution. Local 
communities asked the law enforcement authorities to stop the illegal mining activities and to be fair to the local people but there was no response from the authorities.

Strategic alliances between regulators, power institutions (legislative, executive) as epicenterum of rampant rent-seeking and corruption practices in the mining business. Various modes of conspiracy in mining activities, the term "coordination funds" and quota of thugs, the term that has been familiar to the mining community. Both terms actually reflect the depravity in the mining management system (bad mining practice management) that happened so far. The term co-ordination funds, ie, a sum of money flowing to officials or to security personnel, individuals, or interest groups (mass media, NGOs, mafia mines) involved in the illicit practices of the mining business. The mode is increasingly structured to work in the system under cover. One mode that runs so far is happening in mining ports when delivering coal out of the region and abroad. This is a mafia miner that looks legal by involving various parties. It has become a land of corruption for local officials, security officers from the village level to the district, provincial, and even down to the central level.

According to Didik Gunawan, journalist, explains that: "This is a systemic mine practice of mafia. One of them is the coordination fund that flows to the officials, security officers, and other groups that have been running for so long and have never been touched by the law ". The term co-ordination fund is an extra fund issued by entrepreneurs as a security fund to facilitate a dark conspiracy, corrosion, and mafia mining. A number of these funds have been calculated and prepared by its own budget by the mining business. The amount of funds spent for once or a barge that dispatched value tens of millions of rupiah. The number flows to several officials including: Kapolsek, Danramil, Camat, Syahbandar, Police,, Military District Command, Police Resort, and local officials. The amount varies according to the level of position and function of the official concerned", (Interview in Banjarmasin, April 10. 2017)

Coal mining delivery activities outside the region and abroad through several mining ports are scattered in several locations in Tanah Bumbu. From some of these ports, the owners are local miners, local and central government officials (Jakarta) who have business networks in the region. Here are a number of coal ports scattered in several locations in Tanah Bumbu: Langgengnya practice of conspiracy structured in the mining business, due to the power of funds issued by mining entrepreneurs flowing to a number of local bureaucratic officials and security officers. Then apply the term wet areas and arid regions that describe the position stratification of the person. Stratification is important because of the large amount of funds received from mining entrepreneurs. For unscrupulous person, but the status of apparatus looking for another way that is not inferior to the recipients of the quota allotment.

Related to this, it is undeniable that there are a number of unscrupulous personnel involved in doing business by supplying various needs related to mining activities, for example, providers of oil ingredients, into coal brokers, or become bodyguard at the mine site. Delivery activities of coal out of the region and abroad through several mining ports scattered in several locations in Tanah Bumbu. From some of these ports, the owners are local miners, local and central government officials (Jakarta) who have business networks in the region. Here are a number of coal ports scattered in several locations in Tanah Bumbu: This conspiracy practice lasts of conspiracy in mining business, due to the power of funds issued by mining entrepreneurs flowing to a number of local bureaucratic officials and security officers. Then apply the term wet areas and that describe the position stratification of the person. Stratification is important because of the large amount of funds received from mining entrepreneurs. For unscrupulous person, but the status of apparatus looking for another way that is not inferior to the recipients of the quota allotment. Related to this, it is undeniable that there are a number of 
unscrupulous personnel involved in doing business by supplying various needs related to mining activities, for example, providers of oil ingredients, into coal brokers, or become bodyguard at the mine site.

The world of mining industry is a business activity loaded with the complexity of the problem. The complexity of the issue appears to be closely related to the regulatory system, institutions, and behavior of actors in mining management. Regulatory and institutional engineering are legally protected instruments by interested parties to engage in corrupt or mafia mining practices. The involvement of local authorities and related institutions in the management of mining policy is difficult to avoid. In the era of democratization accompanied by decentralization policy and local autonomy, in the context of natural resource policy management, local authorities as regulator owners with their own authority have used the regulation and institutions of power as elite capture corruption.

\section{Conclusion}

The fall of Soeharto's 1998 political rule after 32 years has resulted in a democratic transition from an authoritarian-centralist governmental system to a decentralized democraticgovernment system. The political changes that occurred after the fall of the Soeharto government were not only in the context of governance, but also in the context of natural resource management. As it is known that during Soeharto's rule, the policy on natural resource management was controlled by the business cronies and Suharto's relatives in a centralistic manner and gave no opportunity for the regions to control or manage the natural resources in the region. As a result, due to unfair and transparent management, the natural resources in the area simply disappeared but did not positively impact and growth and development for the region, in particular creating justice and prosperity for local communities. Worse yet, the result of uncontrolled exploitation has caused a number of serious problems such as environmental disasters, the poverty of local communities due to the loss of economic resources of communities in the mining area.

Since decentralization policy have been applied to local authorities in the management of natural resources, it has become an opportunity to build a conspiracy or robbery to accumulate regional economic resources through a set of policies, regulations, or regulations. It has spawned a crony of business or economic patronage of local elites who use position or power institutions. Therefore, some local officials are trapped by corruption practice and abuse of power in issuing mining licenses for entrepreneurs.

Exploitation of mining industry took place in several regency in South Kalimantan Province, formerly beautiful villages and dense forests lost and extinct have been transformed into mining areas. Now the villages had turned into a frightening ghost despair frenzied by the heavy machinery of the mine. Many displaced villagers leave the village to seek new livelihoods or go abroad to cities seeking economic livelihoods. They have to leave their hometown for decades. As far as the eye could see only the deep holes formed rivers. Forests are barren without a tree being filled. The song of birds is no longer heard by the sound of mining machines. Pollution and environmental chaos are getting worse. The rivers have been polluted and the water has changed color. The animals are no longer a place to feed grass. Everything is gone and extinct. This world of mining industry is a world full of exploitation and greed. The neglect of illegal mining and corruption and rent-seeking practices is the accumulation of bad governance practices of coal mining management.

South Kalimantan Province as the second largest mine producer is not directly proportional to the sustainability of its masrakat. The Human Development Index ranks at 26th of 34 provinces in Indonesia. This can be seen in the province of South Kalimantan from 
indicators of lagging economic, education and health infrastructure developers. This is a paradox as a coal mine producing region but it is a problem of underdevelopment and high poverty.

As a leading argument that abundant natural resources turn out to be just a myth and a nightmare for the masses. There are many factors that can be argued, that the management of natural resources is still poorly managed because of incorrect systems and regulations. The policies that are more profitable to entrepreneurs only and not benefit all parties. Local officials are already feeling good about this chaotic system and people have no chance to control and criticize. Meanwhile, social institutions such as NGOs do not play much because they are already dominated by bribery practices and have been tamed with various facilities and lure proyak by local authorities. Similarly, the mass media can not do anything as a social control because the media has been tamed by the mining predators through various ways to not expose the bad management of natural resources.

Regional officials are engrossed in developing transitional politics with mining entrepreneurs and many mining entrepreneurs are involved as fund sponsors in local elections. Therefore, it is only natural that for decades the presence of the mining industry is merely a myth and a nightmare behind decentralization and regional autonomy policies. Yes, that is the curse of natural resources or the tragedy of the commons as it is dyediced by experts over. This paper is an intellectual reflection that is concerned about the poor mining industry that has been running for this. As an academic this is all I can do and provide advocacy and enlightenment for the local community as long as I can do. Hopefully this paper can provide enlightenment for us wherever we are. Again, hopefully useful from this very simple reflection of thought.

\section{References}

Aspinall, E, As'ad, M.U (2015), The Patronage Patchwork Village Brokerage Networks and the Power of the State in an Indonesian Election. Journal of the Humanites and Social Sciences of Southeast Asia, volume 171 Issue 2-3, pages 165-195 BijdragentotdeTaal-Landen

Aspinall, E, As'ad, M.U (2016), Understanding Family Politics: Succsses and Failures of Political Dunasties in Regional Indonesia, South East Asia Reseacrh, SAGE, 2016.

As'ad, M.U (2015), Election, Mining, and Collaboration State and Market: An Empirical Evidence in Province of South Kalimantan, Indonesia, Institute of Politics and Policy Studies, Nabila Publishing, Banjarmasin, Indonesia

As'ad, M.U, (2017), Political Patronage Network: Involvement of Mining Entrepreneurs in Pilkada in South Kalimanatn, Indonesia, Faculty of Social and Political Sciences Islamic University of Kalimantan, Banjarmasin Indonesia

As'ad, M.U, (2016), Political Business Mining In Conspiracy Pilkada in SouthKalimantan, Genta Publishing, Yogyakarta, Indone

As'ad, M.U, (2016), Democratic Capitalization, Local Actors, and Political Patronage Networks, in Journal of Social and Political Science, As Siyasah, Islamic University of Kalimantan, Indonesia

Agrawal, A. 2003. Sustainable Governance of Common-Pool Resources: Context, Methods, and Politics. Annual Review of Anthropology 32:243-262.

Agrawal, A. 2005. Environmentality: Technologies of Government and the Making of Subjects. Durham, NC: Duke University Press. 
Auty, R. (1994), Industrial Policy Reform in Six Large Newly Industrializing Countries: The Resource Curse Thesis, World Development, 22.

Auty, R. (2001), Introduction and Overview. In R. Auty (ed), Resource Abundance and Economic Development, Oxford: Oxford University Press.

Bardhan, P and Dilip Mookherjee, (2011), Political, Clientelism and Capture: Theory and Evidence From West Bengal, University of California, Berkeley. . I California,Berkeley

Bardhan, P and D. Mookherjee, (2000a) 'Corruption and Decentralization of Infrastructure Delivery In Developing Countries', University of California, Berkeley, 2000a.

Erman, E, (2005), Illegal Coalmining in West Sumatera: Access and Actors in the PostSeoharto Era, The Politics and Economics of Indonesia's Natural Resources, Edited by Budy P. Resosudarmo, Singapore: Institute Southeast Asian Studies.

Fatah, L, Udiansyah, M. Handry Imansyah, Gt. Khairuddin (2007), The Impacts Of Coal Mining on the Economy and Environment of South Kalimantan Province, Indonesia Faculty of Agriculture Lambung Mangkurat University South Kalimantan, Indonesia

Gylfason, T. (2001). Natural Resources, Education, and Economic Development. European Economic Review 45, pp. 847-859.

Hardin, G. (1968). The Tragedy of the Commons. Science 162:1243-1248.

Maimunah, Siti, (2012), State of Mine and Indigenous Peoples: Human Rights Perspectives in Mining Management Based on Environment and Local Wisdom: Intrans Publishing, Malang, East Java.

McCarthy. J. (2001), Decentralisation, local communities, and forest management in Barito Selatan District, Central Kalimantan. Case Studies on Decentralisation and Forests in Indonesia No. 1. Bogor, Indonesia: CIFOR.

McCarthy. J. 2004. Changing to gray: Decentralization and the emergence of volatile socio-legal configurations in Central Kalimantan, Indonesia. World Development 32(7): 1199-1223

Ostrom, E. (1990) Governing the Commons: The Evolution of Institutions for Collective Action. New York: Cambridge University Press.

Rosser, A. (2007), "Escaping the Resource Curse: The Case of Indonesia." Journal of

Sachs, J, and Andrew Warner, 1995, "Natural Resource Abundance and Economic

Growth," in G. Meier and J. Rauch, eds., Leading Issues in Economic Development

New York: Oxford University Press. NBER WP 5398

Sachs, J, and Andrew Warner,(2001), "The Curse of Natural Resources," European

Economic Review (Elsevier), vol. 45(4-6), pages 827-838, May.

(eds.) Taxat ion and Development: The Weakest Link, Edward Elgar, Cheltenham,

Salamudin. (2011). Colonization of the Mining Hole. Temali Foreign Capital, Debt and Dredging of Mining Wealth in Indonesia, JATAM and In-TRANS Publishing,Malang

Syeirazi, Kh, M, (2009), Under the Foreign Flag: Liberalization of Oil and Gas Industry in Indonesia, LP3ES, Jakarta.

Tadjoeddin, M. Z, (2007), A Future Resource Curce in Indonesia: The Political Economy of Natural Resources, Conflict and Development, Qoeen Elizabeth House, University of Oxford. 